The Social Sciences 7 (4): 568-574, 2012

ISSN: $1818-5800$

(C) Medwell Journals, 2012

\title{
The Development of Higher Education in Malaysia: An Ethnic Relations Perspective
}

\author{
Nazri Muslim and Rozita Ibrahim \\ Center for General Studies, Universiti Kebangsaan Malaysia, Bangi, Selangor, Malaysia
}

\begin{abstract}
Ethnicity refers essentially to the socio-cultural characteristics of a person. Ethnicity is characterized by one's culture, language, religion, national origin and others. Thus, an ethnic group comprises of members who have a set of socio-cultural characteristics of their own. They have the same cultural practices and share similar historical background, value systems, attitude and behaviour. In Malaysia, there are three major ethnic groups, namely the Malays, Chinese and Indians. In the Malaysian context, ethnicity is also an important aspect in the identification of one's religion as well as giving a clue of their affiliated political parties. The interplay between these various factors associated to ethnicity provides an interesting background to the study of Malaysian history and development. In this study, the researchers discuss the development of Malaysian higher education from an ethnic relations perspective. The study is based on the review of relevant literature and documents related to the history and development of higher education in Malaysia and its connections to ethnic integration towards nation building. This research discusses the various phases in the development of Malaysian higher education from the colonial times to the current globalisation era. The research highlights the efforts taken by the government in promoting and maintaining ethnic integration through education at the tertiary level.
\end{abstract}

Key words: Plural society, higher education, nation building, ethnic relations, development, Malaysia

\section{INTRODUCTION}

Ethnicity refers essentially to the socio-cultural characteristics of a person. Ethnicity is characterised by one's culture, language, religion, national origin and others. Thus, an ethnic group comprises of members who have a set of socio-cultural characteristics of their own. They have the same cultural practices and share similar historical background, value systems, attitude and behaviour. According to Schaefer (2002), ethnicity refers to the differences in culture such as language, attitude towards marriage and parenthood as well as eating habits. This agrees with Ting Chew Peh's understanding of ethnicity as a socially defined concept based on cultural characteristics such as norms, family patterns, sexual behaviour, clothing and views on beauty, political orientation, economic activity and patterns of entertainment. In fact, the concept of ethnicity has been adopted by the Malay world before the coming of the Western colonial powers. For example at that time, the Malays were defined based on the concept of ethnicity and not by the concept of race. This has always been the case because the concept of race complicates the categorisation of the Malays due to the mixing of three phenotypes. The first phenotype refers to the Caucasian, i.e., the English, Dutch, Turkish, Arabs, Portuguese, Indians and others. The second phenotype involves the Mongoloid like the Chinese, peoples of the Malay Archipelago and the aborigines while the third phenotype refers to the African people. The integration of the above mentioned three phenotypes resulted in the blurring of the physical characteristics of the Malays, thus complicates the use of the concept of race.

The focus of this study is on the case of Malaysia which is a developing country located in the Southeast Asia. The total population of this country is $>26$ million comprises of various ethnicities and religions. The major ethnic groups are Malays $(50.3 \%)$, Chinese $(23.8 \%)$, non-Malay indigenous people (11.0\%) and Indians (7.1\%). The Malays and non-Malay indigenous people together make up the Bumiputera or son-of-the-soil group. The Malay culture lies at the core of the Malaysian identity, however other ethnic cultures are recognised too. Thus, while the official language in Malaysia is Bahasa Melayu or the Malay language, other languages such as English, Chinese, Tamil and Punjabi are also spoken. Also, while the official religion is Islam which is practiced by about $60 \%$ of the population, the rest of the population practices Christianity, Buddhism, Hinduism and other religions freely. It is also important to note that the Federal

Corresponding Author: Nazri Muslim, Center for General Studies, Universiti Kebangsaan Malaysia, Bangi, Selangor, Malaysia 
Constitution stipulated that Malays are by definition Muslims. Ethnicity, apart from being an important aspect of identification of one's religion, can also provide us with a clue of one's affiliated political party. Generally speaking, the discourse of ethnic relations in Malaysia can be divided into four categories. The first category refers to the dominance of the pre-independence discourse of Malay supremacy; second, the melting pot concept; third, discourses on a multicultural society consisting of diverse cultures and religions while the fourth is a multi-ethnic society in which every ethnic group are given equal opportunity. In this study, the researchers aim to illustrate the long process of negotiation between the ruling government and the diverse ethnic groups in Malaysia, by focusing on the case of Malaysian higher education development and policies. To begin with, the researchers will provide a brief description on the history of Malaysian multiethnic society and how education plays an important role in ethnic integration and nation building.

\section{EDUCATION AND NATION BUILDING IN MULTIETHNIC MALAYSIA}

Historically speaking, before the European came to the Southeast Asia, the area had always been characterised by plurality (Shamsul, 2010a). Plurality refers to the natural process of migration and cultural borrowings and adaptations that resulted from different ethnic encounters that happened in the region. In terms of the society's political order:

A flexible non-bureaucratic style of management focusing on management and ceremony by a demonstrative ruler. States, governments and nation-states which constitute an elaborate system of bureaucratic institutions, did not really exist until Europeans came and dismantled the traditional polities of Southeast Asia and subsequently, installed their systems of governance, using 'colonial knowledge' which gave rise to the plural society complex (Shamsul, 2010b)

In the case of Malaysia then known as Malaya, colonial occupancy was a long one starting with the arrival of the Portuguese in 1511, followed by the Dutch in 1641 and later by the British in 1874. Also, there was a short period of Japanese occupation from 1941-1945 which was later taken over by the British again. In terms of influences, it was the British that brought about most changes that happened in Malaysia in terms of social, political and economics. It is important to note that while these changes came during the British era, they were built from the plural society context that was mentioned by Shamsul (2010a, b).

One of the major changes during the British era came in the form of foreign workers who were brought in, to develop the economic sector. A huge number of foreign immigrants came in from mainland China and the Indian subcontinent. The Chinese were located in the urban areas to work in the commercial and mining sectors while the Indians worked in the plantation areas, especially at the rubber estates. The Malays who were the native people of Malaya were mainly farmers and fishermen who lived in the rural areas. This trend in population based on economic activities and place of residence were prevalent at the time when Malaysia gained independence. Then, the Malaysian society was comprised of three major ethnic groups where the Malays accounted for almost $50 \%$ of the population while the Chinese made up $37 \%$ and the Indians, $11 \%$. The British divide and rule policy had resulted in economic and social imbalance amongst these major ethnic groups in the newly independent country and this is also apparent in the field of education. The British colonial policies and attitudes towards education were determined by the economic roles of the Malays, Chinese and Indians. Hence, different types of schools were established for these ethnic groups. Generally speaking, the objectives of British education system were to provide most children with basic education in their own languages so as to prepare them to work in the respective economic sectors associated with their ethnicities. Thus for the Malays, schools were established in the rural areas aiming at providing basic education. Ismail and Musa (2010) quote the statement by a senior British officer for the Federated Malay States in 1920 :

The aim of the government is not to turn out a few well-educated youths, nor yet numbers of less well-educated boys; rather it is to improve the bulk of the people and to make the son of the fishermen or peasant a more intelligent fisherman or peasant than his father had been and a man whose education will enable him to understand how his own lot in life fits in with the scheme of life around him

For the Chinese, education was meant to maintain ties with China while for those studying at the English medium schools, the aim was to pass the Cambridge Overseas Certificate examinations. These English medium schools were of higher standards and were located in urban areas. Obviously this only benefited a small number of Malay elites and the Chinese and Indians who lived in those urban areas. This: 
Pyramidal colonial education system in the period of 1786-1957 had created a grave imbalance in the distribution of opportunities for education (Selvaratnam, 1988)

Therefore in the years prior to independence, there was a wide gap in income distribution that can be associated with ethnicities and geographical locations between the majority of the Malays and the non-Malays. Besides that there were no common goals between these ethnic groups that would soon live together in independent Malaysia. Thus, it was clear to both British colonials and Malaya's new elites who were preparing to take over administration of the country that nation building was a necessity and education was central towards this end. Nevertheless, there were disagreements on language issues (Brown, 2007) where:

... the non-Malay elites predominantly favouring English (or English and Malay) as the national language and the Malay nationalist of UMNO favouring Malay only. The compromise that was eventually struck was for Malay to be adopted as the national language with provisions for English to be used for 10 years after full independence was attained in 1957

The newly independent Malaysia was also faced with the problems of socio-economic imbalances between the Bumiputera and non-Bumiputera that resulted in an ethnic riot in May, 1969. This incident forced the government to introduce an affirmative action for the Bumiputera through the New Economic Policy (NEP). Another important response was to promote national integration and unity through the education system, as education was seen as an important medium for upward social mobility, thus helping to rectify the problems of Bumiputera backwardness.

In this regard, the Malay language was made the medium of instruction at state-assisted secondary schools and state examinations were restricted in the same language too. However while private secondary Chinese schools were allowed to continue, their examinations were not recognised by the government, thus denying entrance into public universities and getting jobs in the public sectors. As for primary schools, Chinese and Indians were allowed to continue having their mother tongue as the medium of instructions at vernacular or national-type schools while a common curriculum was instituted by the government. The changes that took place after the ethnic riot in 1969 were accepted by the Malays and non-Malays but it was never without contestations. Issues related to ethnic preferences and demands, sometimes inter-ethnic and at other times intra-ethnic, remain crucial in Malaysia (Ibrahim, 2007). However in this study, the researchers are interested in discussing the development of education at tertiary level. What happen to students from various types of schools upon finishing their seconday education? How does development at school level influence higher education in Malaysia? Phases in the development of higher education in Malaysia. In this study, researchers will discuss the three phases of development in higher education in Malaysia. First, from the colonial period up to independence in 1957; second, the period after the ethnic riot in 1969 and third, the present period of globalisation. All three phases have changed the Malaysian higher education landscape and impacted upon, as well as being shaped by ethnic relations in the country.

\section{THREE PHASES IN MALAYSIAN HIGHER EDUCATION DEVELOPMENT}

From colonial period to independence of Malaysia in 1957: Higher education was not a priority in the British colonial education policy. Those privileged few who enjoyed good English education in Malaya gained their higher education in Sing apore or enrolled in matriculation courses at universities in Hong Kong or the United Kingdom (Ismail and Musa, 2010). Also, there were some Malays from rich families who enjoyed the rise in rubber prices at that time who had the chance to further their studies in the Arab countries, especially in Mecca in Saudi Arabia and Al-Azhar University in Egypt. They were mainly students from Islamic oriented schools or madrasah, e.g., Madrasah al-Masyhur in Penang, Madrasah Muhammadiah, Kota Bahru and al-Ihya al Syarif, Perak (Zain et al., 2005). As for higher education development in the then Malaysia, Ismail and Musa (2010) stated that:

...formal education in Malaysia before independence can be examined from two aspects:

English education and Malay education

Higher education in the English medium began with the setting up of two colleges in Singapore: King Edward VII College in 1905 and Raffles College in 1928. Higher education in the Malay medium, on the other hand, began with the establishment of the Malacca Training College in 1901, the Matang Training College in 1913 and the SITC (Sultan Idris Teaching College) in 1922. King Edward VII College is a Medical College which was developed following the petition by Chinese leaders in Singapore with the objective of training assistant surgeons and doctors. Later, the initial diploma level was upgraded and 
the students were trained for a professional career. Raffles College, on the other hand, catered for fields other than medicine. The college also provided training for teachers as well as offering scholarships for postgraduate studies for selected students. In the area of Malay higher education, all of the colleges were focusing on teacher training.

The British educational development in Malaysia was disrupted during the short period of Japanese occupation. The education policy was revised after World War II ended and the policy outlined three main principles (Ismail and Musa, 2010). First, education should be directed at instilling, encouraging and increasing the capacity of self-rule, apart from loyalty and responsibility. Second, equal opportunity should be given to all children, both boys and girls irrespective of race. Third, there was also a need to develop secondary, vocational and higher education that is capable of meeting the needs of the country. The outcome of this policy was manifested with the establishment of University of Malaya (UM) in Singapore, in October, 1949 through the merging of King Edward VII College of Medicine and Raffles College.

In terms of ethnic relations, it is interesting to note that a total of four pro-chancellors were appointed. They were the High Commissioner of Malaya, the Governor of Singapore, Sir Han Hoe Lim who was a member of Carr-Saunders Commission (the commission that suggested the merging) and Dato' Onn Jaafar who was a Malay leader at that time. This was to show that the establishment of University of Malaya will not cause any loss for the Malays and that the university is open to all ethnicities. This was echoed in an article written by Silcock, as quoted by Ismail and Musa (2010) stating that a university must demonstrate the multicultural lives of its students as well as maintaining a high academic standard and not only producing graduates like a factory. Later, upon independence in 1957, political and educational considerations brought about the establishment of UM in Kuala Lumpur in 1959 which was then separated as an entity on its own in 1962. Following that the Singapore UM came to be known as University of Singapore.

As a newly independent country, efforts were taken to to develop education that balanced between vocational studies and overall intelectual development. Hence in 1962, the Higher Education Planning Committee was formed with the aims to identify the workforce needed in a 20 years period and also to plan the educational facilities towards producing the required workforce (Ahmat, 1980). This is clearly seen in the First Malaysia Plan (1966-1970). In years to come, the establishments of new universities in Malaysia would be focusing on providing the much needed human resources requirements.
After May 13th, 1969 ethnic riot: After the May 13th incident as mentioned earlier, the NEP was introduced to address the problems of socio-economic imbalances between the Bumiputera and non-Bumiputera. Higher education was regarded as one of the most important ways towards restructuring Malaysian society (Moris and Attar, 2010). The NEP introduced the quota system in student admission in order to ensure a balanced ethnic composition, not only in the total population of students but also in the distributions of students according to faculties (Selvaratnam, 1988). Besides, scholarships, special assistance and tuition as well as pre-medical, pre-science and pre-engineering programmes were established for rural students. The government also opened the MARA Institute of Technology (ITM) in 1967 to cater for the higher education needs of the Malays and Bumiputera. In terms of national language as an important tool towards ethnic integration and promotion of national identity, the universities in the country were directed to employ the Malay language as the medium of instruction for all courses by 1983 .

Selvaratnam (1988) notes that the affirmative action that favours the Bumiputera community brought about considerable discontent among the non-Bumiputera, especially the Chinese population of the country. They were of the opinion that the policy discriminated against them and denied them access into local universities. However, according to Brown (2007):

... through the early years of the NEP, Chinese
discontent was relatively contained, largely due
to the acceptance across most ethnic groups that
some form of affirmative action was necessary for
lasting stability and the high growth rates of the
period which mitigated any potential loss by the
non-bumiputera communities. In the mid 80 's
however, against a backdrop of economic
downturn, increased societal protest and
tensions within the BN coalition, education
issues became the focus of more vociferous
ethnic discontent and mobilisation

Brown further stated that this dissatisfaction had brought about ethnic protests, starting with a local issue in UM but later expanding to become a national level dispute. The dispute was intensified by a series of counter-demonstrations organised by various political groups representing the Malays and non-Malays. The ethnic discontents and demonstrations came to a critical level in 1987 and eventually forced the government to detain a number of people under the Internal Security Act (ISA) as well as closing several newspapers and imposing 
bans on all public demonstrations and rallies. This has effectively silenced the social discontent for years to come.

From the late 1980s onwards, the Malaysian higher education sector saw changes with a reduction in the Bumiputera interests, although the quota system was still practised. During this period, the country embarked on democratising higher education (Moris and Attar, 2010). This meant that the opportunity to gain higher education was extended to the masses, regardless of their socio-economic background. Higher education is thus, no longer elitist in nature and does not privilege certain sectors of the community. The 1980's and early 1990's saw the establishment of new government universities such as the International Islamic University (1980), Universiti Utara Malaysia (UUM), Universiti Malaysia Sarawak (1992) and Universiti Malaysia Sabah (1994). Besides that the government started to allow for the establishment of private tertiary education institutions.

This was driven by the limited number of places at public universities combined with the increasing education rates of the population as a whole and the increasing costs of overseas education (Brown, 2007). However, this growth was limited by the fact that private colleges were obliged to accept the Malay language as the medium of instruction. Hence, many Chinese students opted for education in English or Chinese abroad. Later in 1996, the Education Act greatly liberalised the tertiary education sector by allowing for instruction in English language, thus promoting more private universities starting with Universiti Tun Abdul Razak (UNITAR) and Universiti Tun Abdul Rahman (UTAR).

Globalisation era: In the era of globalisation, the role of higher education is closely linked to the emergence of a post-industrial economy, in which productivity relies predominantly on science, technology and management (Lee, 2004). Thus, universities all over the world started their restructuring practices in order to respond to this new development. In Malaysia, this first came in the form of corporatisation of public universities. The aim was to develop corporate culture and practices that enabled universities to compete in the market place. Lee (2004) asserts that:

...instead of producing and transmitting knowledge as social good, the universities are placing emphasis on the production of knowledge as a marketable good and saleable commodity... Universities are engaged with market-related activities

In this country, Lee stated that these changes have also expanded the role of the government from being the main provider to a regulator and protector of higher education. This is in line with the establishment of The Ministry of Higher Education in 2004. Higher education in Malaysia is no longer designed to fulfil the needs of Malaysians only. In this era of globalisation, education is fast becoming an industry and knowledge is seen as a commodity. Promotions and campaigns were carried out in foreign countries to attract students to enrol in local universities. This has resulted in an increasing number of foreign students, especially from developing countries in Asia and Africa. All these new development will certainly bring about a new phase of multicultural encounter to the various ethnicities in Malaysia.

\section{ETHNIC RELATIONS AND HIGHER EDUCATION: THEN AND NOW}

Historically speaking, the colonial education policy had never imagined that Malaya will have many institutions of higher learning. At that time, tertiary education was limited to the elite groups of the country, regardless of their ethnicities. The uniting factor then was that of class or social status and not that of ethnicities. Thus, the problem of ethnic polarisation was rarely raised. Later when the country gained independence, the policies and acts related to education were mainly concerned with the school level (Abdullah and Othman, 2008). These policies and acts did not affect the tertiary education. The main aim then was to promote national integration among the younger generation who are still in their primary and secondary schooling period. This was done by inculcating the relevant values into the primary and secondary school curriculum. As for the universities, there was no standard curriculum that aims at promoting integration between different ethnicities. Perhaps, the policy of making the Malay language as the medium of instruction for higher education could be regarded as an effort towards national integration. Nevertheless, this policy that was introduced in early 1983 did not last for long. Later in 1996 due to the democratisation of higher education, the policy changed to allow the usage of English language as the medium of instruction at private universities. In terms of general education curriculum, initially there were no compulsory subjects aiming at national integration at the university level. However, in late 1990's, some universities take the effort to introduce a new subject called The Islamic and Asian Civilisation under the general studies curriculum. However, this newly introduced subject did not have specific goals for inter-ethnic integration. Also, each university have their own system and method of teaching the subject. Thus, it is up to the university to conduct its own policies and 
practices related to ethnic integration. Normally, this falls under the responsibility of the Students Affairs Department. Hassan et al. (2010) suggests that this implies that the higher learning institutions were hoped to continue the integration policies at the school level.

The researchers suggest that the issues of ethnic polarisation at the universities are partly due to the lack of clear policies on nation building at higher education level. For example, the Strategic Plan for Higher Education does not provide specific objectives towards this end (Nazri, 2011). National integration was only mentioned briefly in the efforts towards transformation of higher education. The transformation of higher education is geared towards strengthening the country and the people so as to develop a society that holds the values of democratic, justice, progressive, respect for diversity, integrity and harmony, in facing future challenges. The plan was more focused on seven areas, i.e., widening access and increasing equity, improving the quality of teaching and learning, strengthening research and innovation, strengthening institutions, enhancing internationalisation, cultivating life-long learning and strengthening the delivery system of higher education. As a result, a Report on the Development and Direction of Higher Education, Malaysia has noted the resolutions to ensure that the efforts to foster national unity be extended and enhanced in higher learning institutions. This should be done through the introduction of a course that focuses on intercultural and intra-cultural studies. This course will be made compulsory for all students and the teaching and learning of this course should be implemented through discussion and participation of all students. On top of that students are required to carry out community work and activities and this will be counted in their credit hours. The above resolution has led to the introduction of the Ethnic Relations Module as a compulsory course for all public universities starting in year 2005/2006. The aim of this module is to strengthen ethnic relations among students in tertiary institutions. For private higher institutions, the compulsory course with similar objective is called Malaysian Studies. This can be seen as a positive step towards inculcating awareness and knowledge of Malaysian multicultural society. Other than having a compulsory course in the university curricula, co-curricular activities at the faculties and residential colleges are identified as potential sites where inter-ethnic understanding and relationships can be fostered.

The above discussion shows how nation building and promoting unity among the diverse ethnic groups in Malaysia have been promoted at the structural level. However, the question of whether or not these noble intentions are evident in the everyday social reality
(Shamsul, 2010b) of the university students is yet to be answered. Studies by local scholars indicate two opposing views. First, ethnic polarisation is widening between Malay and non-Malay students (Salim, 1983). Abdul Samad Hadi found that $80 \%$ of his respondents agree that they still have negative prejudices towards other ethnic groups. Though at the outer surface, relations between different ethnicities seem pleasant, students found it difficult to spend time together for social activities such as having meals, studying as a group and even more apparent, many disagree to sharing accomodation as roomates. However on a positive note, the second view states that though ethnic polarisation seems to exist, it is getting less and less due to the shared norms related to contemporary life that focusses on individual needs for material gain, social status and connection that he contends have succeded in overtaking the significance of political and ethnic differences. Another study by Hassan et al. (2010) suggests that university activities have successfully helped in creating awareness and increasing students' motivation to interact with other ethnic groups.

\section{CONCLUSION}

This study discusses the development of higher education in Malaysia from an ethnic relations perspective. The researchers suggest that what we see in today's ethnic relations at local universities is very much a result of the history and development of the education policies as a whole. The objectives of promoting ethnic and national integration has always been central to these policies. The earlier effort that was mainly focused at the school level has now extended to the the tertiary level. For us, the fact that these efforts in promoting unity through education has now reached the higher education and not only concentrated in the school level is a sign that the process of ethnic relations in the Malaysian education system is moving forward towards a new height.

\section{REFERENCES}

Abdullah, H.S. and S. Othman, 2008. The Public University Governance: The Missing Parameters. In: Governance and Leaderships in Higher Education, Shuib, M., S. Kaur and R. Jamaludin (Eds.). Penerbit USM, Pulau Pinang.

Ahmat, S., 1980. Nation building and the university in developing countries: The case of Malaysia. High. Edu., 9: 721-741. 
Brown, G., 2007. Making ethnic citizens: The politics and practice of education in Malaysia. Int. J. Edu. Develop., 27: 318-330.

Hassan, Z., F. Idris, N.A.M. Awal, A. Ya'acob and M.M. Noor, 2010. Contribution of education to enhancing unity: Malaysian experience. Int. J. Learn., 17: 197-206.

Ibrahim, R., 2007. Multiculturalism and education in Malaysia. Cult. Religion Interdisciplin. J., 8: 155-168.

Ismail, A.R. and M. Musa, 2010. History of the Growth and Development of Higher Education in Malaysia Until 2007. In: 50 Years of Higher Education Development in Malaysia (1957-2007), Moris, Z. (Ed.). Penerbit Universiti Sains Malaysia, Pulau Pinang, pp: 1-36.

Lee, M.N.N., 2004. Global trends, national policies and institutional responses: Restructuring higher education in Malaysia. Edu. Res. Policy Pract., 3: $31-46$.
Moris, Z. and S.A.S. Attar, 2010. The Philosophy of Higher Education in Malaysia since Independence to the Present. In: 50 Years of Higher Education Development in Malaysia (1957-2007), Moris, Z. (Ed.). Penerbit USM, Pulau Pinang, pp: 37-63.

Salim, A., 1983. The role of Rukunegara in nation building: A retrospective view. Negara, 2: 26-30.

Schaefer, R.T., 2002. Racial and Ethnic Group: Census 2000 Update. Prentice Hall, New Jersey.

Selvaratnam, V., 1988. Ethnicity, inequality and higher education in Malaysia. Compar. Edu. Rev., 32: 173-196.

Shamsul, A.B., 2010a. Nations-of-Intent in Malaysia. In: His Observations, Analyses and Thoughts, Yusoff, A.Y. and A.B. Shamsul (Eds.). Institut Kajian Etnik, Bangi, Malaysia, pp: 31-49.

Shamsul, A.B., 2010b. Islam Embedded: Religion and Plurality in Southeast Asia as a Mirror for Europe. In: His Observations, Analyses and Thoughts, Yusoff, A.Y. and A.B. Shamsul (Eds.)., Institut Kajian Etnik (KITA), Bangi, Malaysia, pp: 146-170. 